\title{
Review of Equilibrium in economics: scope and limits, edited by Valeria Mosini. London/New York: Routledge, 2007, 322 pp.
}

\author{
DOUGLAS W. MACKENZIE \\ The U. S. Coast Guard Academy
}

Many scholars have already focused on the use of equilibrium concepts in economics. Consequently, we must consider the extent to which new books on equilibrium improve our understanding of this subject. Equilibrium in economics does much to explain the historical development and scholarly value of equilibrium concepts in the natural and social sciences and contains much historical detail for a book of its size.

Chapter 4 by William Dixon and David Wilson should be of great interest this year, as it examines concepts from Smith's Theory of moral sentiments 250 years after their publication, but it would be engaging even without the usual interest generated by anniversaries. The idea that Ken Arrow and Gerard Debreu completed Smith's model with general equilibrium analysis always lacked plausibility. It is also important to realize (as argued convincingly in this chapter) that the modern use of homo economicus as a representative agent hearkens back to Thomas Hobbes rather than to Smith. But this use of Hobbes's homo economicus is even more important than indicated in chapter 4. Modern economists have exported equilibrium concepts to political science, via public choice theory. The Hobbesian assumptions in public choice were not made simply by chance: early public choice theorists were explicit about the influence of Hobbes on their work, and Hobbesian issues remain relevant in public choice theory today. ${ }^{1}$ Thus, Hobbesian behavioral assumptions have found their way back into political science through economics.

Adam Smith was not the only one who rejected Hobbes's view of human nature. In chapter 5, Richard van den Berg examines the work of Achilles Nicholas Isnard, published in 1781. Isnard is largely unknown to modern economists, yet many of his ideas are familiar. Isnard combined mathematical modeling of markets with discussion of how

\footnotetext{
${ }^{1}$ See Deirdre McCloskey's (2006) Inaugural James Buchanan Lecture.
} 
conscious calculation and virtuous habits lead to desirable outcomes. Richard van den Berg notes subtle differences between Isnard and Adam Smith. Further work on Isnard might link to Hayek, as he was influenced by the Scottish Enlightenment and critical of French Rationalism but has perhaps more in common with Isnard than with Smith. Isnard's mixing of conscious calculation and habits in a world where "entrepreneurs do a better job directing economic activity than a central 'administrator' could ever do" does seem consistent with Hayek's concept of spontaneous order.

Chapter 5 suggests that Isnard did more than anticipate Walras. Chapter 1 (by Ivor Grattan-Guinness) examines how Walras, among others, drew analogies between equilibrium in mechanics and market equilibrium. The idea that Walras viewed market equilibrium in mechanical terms is not new, but there is much detail to explore. Grattan-Guinness argues that the influence of mechanics on the work of late nineteenth century neoclassical economists has been overstated. This is notable because, as mentioned in several chapters of this text, many of the early neoclassical equilibrium theorists had engineering backgrounds and one might expect that mechanics would strongly influence economic theorizing by engineers. It is also the case that the Austrians who initially developed the non-mechanical version of marginal value theory were all educated in law. ${ }^{2}$ Yet we must not assume too much regarding the influence of anyone's educational background on any subsequent scholarly work.

Chapters 2 and 3 show how equilibrium concepts moved back and forth between economics and chemistry or biology. For example, economics influenced the La-Chatelier-Braun principle in chemistry, and Paul Samuelson in turn used this equilibrium concept in his highly influential Foundations of economic analysis. Chapter 6 reveals the depth of Cournot's work on political, in contrast to Walras's purely mechanical approach to economics.

While the history of science is interesting, the real strength of this book is in its critique of modern economics. Chapters 7, 12, and 13 contain strong critiques of modern equilibrium analysis. Tony Lawson draws a sharp distinction between the examination of real social structures and the fictitious nature of formalistic equilibrium modeling. Alan Freeman argues that neoclassical economists transformed the

\footnotetext{
${ }^{2}$ Carl Menger, Eugen Bohm-Bawerk, Friedrich A. Hayek, and Ludwig von Mises all studied law in Austria.
} 
equilibrium concept they borrowed from physicists, and used it in a religious fashion. Andy Denis attributes the failure of modern equilibrium analysis to its denial of the micro-macro divide. Denis prefers dialectics to static equilibrium analysis and macro analysis leads to dialectics because macro models entail equilibration, but not any final equilibrium.

Chapters 8, 9, and 11 take more balanced and pragmatic views of equilibrium analysis in economics. Warren Samuels seeks to refocus attention away from the stability and uniqueness of equilibrium, and towards equilibration and dis-equilibration. As one might expect, Victoria Chick finds great merit in Keynes's use of equilibrium in particular. Roger Backhouse advises caution in reacting to some of the more harsh condemnations of equilibrium economics, on the grounds that the term equilibrium has many meanings.

While Equilibrium in economics is highly informative, it did leave some areas of interest unexplored. There is little mention of the early twentieth century Stockholm School in this book. Wicksell is mentioned briefly on page 30 , but there is surely more to say about the ideas and influence of this great economist. Someone might also have written at length on Lindahl and Cassell. The use of equilibrium concepts by Swedish economists is worthy of attention on its own. Furthermore, the connections between the Stockholm School and Keynes, and also the Austrians, might have been worth exploring in this volume. For that matter, this book has little to say about Austrians other than Hayek. Ludwig Lachmann and Mario Rizzo have advanced thoughtful critiques of equilibrium economics, but readers of Equilibrium in economics must look elsewhere to learn about these ideas. The work by Henry Davenport and Frank Knight might also have been worth more attention. There is also much to be written on the use of equilibrium models in public choice theory and new institutional economics. Both public choice and new institutional economics started as low-tech real world orientated research programs. Yet over time both of these programs adopted hightech equilibrium analysis. Discussion of the ideas mentioned in this paragraph would lengthen this book, however Equilibrium in economics is not overly long in its present form, and the inclusion of a wider range of perspectives would better inform its readers. Furthermore, a wider range of perspectives might also have drawn a wider audience.

Equilibrium in economics will prompt its readers to undertake an important task: the critical evaluation of the equilibrium concept as 
used throughout the history of economics. We should think critically about equilibrium because, as one of the authors of this volume notes, economics is in an unhealthy state because of the way we use equilibrium. The problem with equilibrium is not merely that many economists use this concept badly, but that many of us use it thoughtlessly. The difficulty in addressing the thoughtless use of equilibrium concepts by many economists is that it is exactly this practice which leads many economists to ignore the type of essays contained within Equilibrium in economics.

\section{REFERENCES}

McCloskey, Deirdre. 2006. The Hobbes problem, from Machiavelli to Buchanan. Inaugural James Buchanan Lecture, April 7th 2006.

Mosini, Valeria (ed.). 2007. Equilibrium in economics: scope and limits. London and New York: Routledge.

Douglas W. MacKenzie is a visiting assistant professor of economics at The U. S. Coast Guard Academy. His main research interests are on the theory of the firm, public choice, market equilibrium, and the history of the interwar years.

Contact e-mail: <dmackenz_2000@yahoo.com> 